\title{
Red-Yellow Latosol Penetration Resistance Under Different Subsoiling Depths
}

\author{
Saulo Boldrini Gonçalves ${ }^{1}$ (D), Eduardo da Silva Lopes $^{1}$ (D), \\ Karina Maria Vieira Cavalieri-Polizeli ${ }^{2}{ }^{\circ}$, Nilton Cesar Fiedler ${ }^{3}{ }^{\circ}$, \\ James Stahl ${ }^{4}$ \\ ${ }^{1}$ Universidade Estadual do Centro-Oeste (UNICENTRO), Irati, PR, Brasil \\ ${ }^{2}$ Universidade Federal do Paraná (UFPR), Curitiba, PR, Brasil \\ ${ }^{3}$ Universidade Federal do Espírito Santo (UFES), Jerônimo Monteiro, ES, Brasil \\ ${ }^{4}$ Klabin S.A, Telêmaco Borba, PR, Brasil
}

\begin{abstract}
The objective of this work was to evaluate the penetration resistance (PR) of a red-yellow latosol submitted to two subsoiling depths for implanting a forest plantation. The subsoiling was evaluated at $40 \mathrm{~cm}$ (S-40) and $50 \mathrm{~cm}$ (S-50) of depth by determining the soil moisture and soil density, while soil PR was evaluated before and after subsoiling at five points transversely to the subsoiling line (furrow) up to a depth of $60 \mathrm{~cm}$ using an electronic penetrometer. The soil density in both treatments was not altered by soil management. Before soil preparation, the soil presented PR values above the critical limit in the $0 \mathrm{~cm}$ to $30 \mathrm{~cm}$ layers, and after subsoiling a reduction in those values was verified at depth. It can be concluded that the $50 \mathrm{~cm}$ (S-50) subsoiling depth is the most suitable for soil preparation in a forest stand implantation.
\end{abstract}

Keywords: soil preparation, compaction, penetrometer. 


\section{INTRODUCTION AND OBJECTIVES}

Soil compaction is a problem faced by companies when establishing new forest plantations. This is mainly due to the intense traffic of wood harvesting machines in the previous stage, which may cause negative impacts on the ecosystem such as productivity losses in stands and changes in soil physical properties, highlighting the increase in soil penetration resistance (Pincelli et al., 2014; Rodrigues et al., 2018).

Penetration resistance (PR) describes the physical resistance that the soil offers to an external factor that tries to move through it, such as a growing root or a soil preparation tool (Pedrotti et al., 2001). It is an important physical property in the study of soil quality, and even though it provides an indirect indication, it enables comparative evaluation of the structural compaction variability in different management systems and soil types (Ralisch et al., 2008).

Several studies have shown the direct relationship between PR and soil density, with high density values reducing voids, increasing soil mechanical resistance, and consequently hindering crop root system development. Moreover, soil PR is highly dependent on moisture, as the water content inversely influences the soil resistance due to the lubricating effect of the water around the soil particles, and with the decrease there is an increase in PR (Almeida et al., 2008).

Texture also interferes with the penetration resistance values and normally, soils with higher sand content have low resistance, low soil mobilization area and lower working depth and width. In evaluating the subsoiling in two different soils with different textures. Bentivenha et al. (2003) observed that the medium texture red-yellow oxisol presented worse results compared to the clayey Quartzite Neosol in relation to the variables of depth, work width, area and mobilized volume of soil.

Although penetration resistance is affected by density, soil moisture content and soil texture, PR values between 1.5 MPa and 4.0 MPa are considered limiting for crops, while 2.0 MPa is considered a critical limit (CL), preventing the root growth of most crops (Ribon \& Tavares Filho, 2008). The authors also state that soil penetration resistance directly influences plant root and shoot growth, which are directly related to overall plant growth, and are modified by soil tillage systems.
Subsoiling is currently mentioned among the various available soil preparation techniques and has been widely used by forestry companies, due to the action of breaking the compacted layers, reducing root penetration resistance, increasing aeration and internal drainage, and decreasing the surface runoff of soil water (Grotta et al., 2004).

It is important to emphasize that when planting forests, subsoiling is the main method implemented to prepare the soil at depths of $40 \mathrm{~cm}$ to $50 \mathrm{~cm}$, and in some cases, is carried out at up to $60 \mathrm{~cm}$. Preparation costs are significantly reduced when it is carried out at the lower depths; however, when there is a compacted layer, the operation is difficult and can cause damage due to a decrease in the yield of the installed crop.

Therefore, it is necessary to carry out studies under field conditions to evaluate the appropriate subsoiling depth for planting forests in different soil types, as well as to determine the soil preparation effect in rupturing the compacted layer and in the volume of tilled soil. The proposed hypotheses are that the different subsoiling depths influence the soil PR values; and there is a decrease in PR values below the subsoiler working depth due to the action of the equipment rod.

The objective of this work was to evaluate the penetration resistance of a sandy red-yellow latosol submitted to two subsoiling depths for planting forest stands, aiming to show the importance of this parameter in evaluating the effects of the preparation systems on the compacted layer and on the volume of tilled soil.

\section{MATERIALS AND METHODS}

\subsection{Characterization of the study area}

The study was conducted in the operational areas of a forest company located in the municipality of Telêmaco Borba, Parana state, between the geographical coordinates of latitude $24^{\circ} 21^{\prime} 24^{\prime \prime}$ South and longitude $50^{\circ} 37^{\prime} 18^{\prime \prime}$ West. The soil of the study area was classified by the company as sandy texture red-yellow latosol (RYL).

The stand installed in the study area prior to the subsoiling operation consisted of Pinus taeda, with a cutting age of 32 years, basal area $44.3 \mathrm{~m}^{2} \mathrm{ha}^{-1}$, $2.5 \times 1.7 \mathrm{~m}$ spacing, diameter at breast height $(\mathrm{DBH})$ of $41.3 \mathrm{~cm}$ and average volume per hectare of $667 \mathrm{~m}^{3} \mathrm{ha}^{-1}$. 


\subsection{Subsoiling}

The subsoiling operation was carried out by a crawler tractor with gross power of $170 \mathrm{HP}$, an operating weight of 19,000 kg, ground track pressure of $53 \mathrm{KPa}$ and fitted with a V-shearing blade $3.86 \mathrm{~m}$ in length and $1.16 \mathrm{~m}$ in height. The tractor was coupled to the single rod trawling subsoiler weighing $5,390 \mathrm{~kg}$, lifting rod adjusted to reach depths of $40 \mathrm{~cm}$ and $50 \mathrm{~cm}$ at the midpoint of the furrow, straight rod and wing tip, curve discs, compression roller and reserve fertilizer container with a capacity of $700 \mathrm{~kg}$. The operation was performed in conjunction with the base fertilization with the tractor-subsoiler assembly.

\subsection{Sample procedure}

The experiment was carried out in a randomized complete block design, three blocks per treatment. The treatments were defined as the different subsoiling depths: S-40 - subsoiling depth of $40 \mathrm{~cm}$; and S-50 subsoiling depth of $50 \mathrm{~cm}$.

The sampling procedure adopted in this study considered each soil preparation line as a composite sample unit. Ten lines systematically distributed in the area were sampled in each treatment, and 15 points were collected, thereby forming a mesh of 150 sample points. The starting point position was determined by drawing the distances to the carriers, and only the preparation lines with more than $200 \mathrm{~m}$ length were considered in the draw. The plots were installed from a minimum distance of $20 \mathrm{~m}$ from the carriers in order to allow for the equipment to stabilize in performing the operation.

The soil PR was determined in two moments: before subsoiling at depths of $40 \mathrm{~cm}$ and $50 \mathrm{~cm}$ (BS-40 and BS-50) and after subsoiling at the same depths (AS-40 and AS-50), with five sampling lines obtained. A transect was allocated transversely to the furrow in each of the lines using a measuring tape, and it was composed of six collection points. The collection points were obtained at the central point of the furrow $(\mathrm{CP})$ and two points on the left $(\mathrm{P}-20$ and $\mathrm{P}-40)$ and on the right $(\mathrm{P}+20$ and $\mathrm{P}+40)$, with equidistant intervals $20 \mathrm{~cm}$ from each other, in addition to a point located between the furrow (BFP).

\subsection{Physical properties of the soil}

To determine the volumetric moisture $(\mathrm{Vm})$ and soil density (Sd), 10 samples with preserved structure were randomly collected per plot using a soil sampler and volumetric rings of $100 \mathrm{~cm}^{3}$ obtained from the center of the layers from $0 \mathrm{~cm}$ to $10 \mathrm{~cm}, 10 \mathrm{~cm}$ to $20 \mathrm{~cm}, 20 \mathrm{~cm}$ to $40 \mathrm{~cm}$, and $40 \mathrm{~cm}$ to $60 \mathrm{~cm}$. These samples were collected at two moments, before and after the soil preparation in the study area. However, after preparing the area, care was taken to remove the samples outside the subsoiling line, where the soil had been tilled.

After collection, the samples were stored in plastic bags and kept at a temperature of $\pm 5^{\circ} \mathrm{C}$ for laboratory analysis. The current moisture and volumetric ring method was used for determining $\mathrm{Vm}$ and $\mathrm{Sd}$, according to the methodology proposed by the Brazilian Agricultural Research Corporation (Embrapa, 1997).

\subsection{Evaluation of soil penetration resistance}

In the PR evaluation, a 06.15.SA Eijkelkamp digital electronic penetrometer was used equipped with a coneshaped tip, with a vertex angle of $60^{\circ}$ and a base of $1 \mathrm{~cm}^{2}$ (11.28 mm nominal diameter). A penetration velocity of $2 \mathrm{~cm} . \mathrm{s}^{-1}$ was applied, controlling the force applied at the moment of penetration by a load cell. The data were obtained according to the recommendations of the Asae Standard 313 , and the readings were performed in intervals of $1 \mathrm{~cm}$ to the depth of $80 \mathrm{~cm}$, obtaining two readings for each sampling point, and later using the mean value obtained between the two readings.

After obtaining the mean PR values, only the values up to the $60 \mathrm{~cm}$ layer were used in the laboratory because it is necessary to know the Vm and Sd values of the evaluated soil layer in order to relate the PR values to the soil compaction. According to Ribon \& Tavares Filho (2008), soil penetration resistance is related to several soil attributes indicating the compaction degree, such as soil moisture and soil density. In using the aforementioned mean PR values, values higher than $2 \mathrm{MPa}$ were determined as the critical limit (CL), as the authors mention that values of $2.0 \mathrm{MPa}$ prevent root growth, therefore is considered the critical PR value.

\subsection{Statistical analysis}

The mean values of $\mathrm{Vm}, \mathrm{Sd}$ and PR obtained at the different subsoiling moments (BS and AS) of the S- 40 and S-50 treatments were submitted to analysis of variance, and the means were compared by the $t$-test at $5 \%$ probability when significant using the Statistica 7.0 program. 


\section{RESULTS AND DISCUSSION}

The mean values of $\mathrm{Vm}$ and Sd in the S- 40 and S-50 treatments at moments before and after subsoiling at the $0 \mathrm{~cm}$ to $60 \mathrm{~cm}$ depth layers are presented in Figure 1.

There was a significant difference between the mean values of soil moisture at the BS- 40 and AS- 40 moments. The soil in the study area was moister before subsoiling when PR was evaluated. This fact demonstrates that the soil moisture conditions may influence higher $P R$ values at the AS-40 moment in relation to the BS-40 treatment. According to Souza et al. (2006), PR presents an inverse relationship with soil moisture, meaning that as the moisture increases, a PR decrease occurs. No significant difference was observed between the mean values of the AS- 40 , BS-50 and AS-50 moments, and therefore it could be stated that the soil moisture did not influence the penetration before and after the $50 \mathrm{~cm}$ subsoiling or between the treatment values at $40 \mathrm{~cm}$ and $50 \mathrm{~cm}$ depth.

Regardless of the subsoiling moment, the soil density did not present a difference for either treatment. Thus, the density conditions in the area did not influence the PR values between the penetrometry performed before and after the soil preparation.

Figure 2 shows the curves resulting from the mean PR values as a function of depth at the BS- 40 and BS-50 moments of the AS- 40 and AS-50 treatments.

Prior to the subsoiling operation, mean PR values ranged from 1.23 MPa to 2.38 MPa (BS-40) and from $1.56 \mathrm{MPa}$ to $2.36 \mathrm{MPa}$ (BS-50) at depths of $0 \mathrm{~cm}$ to $60 \mathrm{~cm}$. All values above the critical limit of $2 \mathrm{MPa}$ were found in the superficial layers of the soil $(0 \mathrm{~cm}$ to $30 \mathrm{~cm})$, and this result can be explained by the mechanized wood harvesting activity previously carried out in the study area, where the main forces causing compaction of forest soils are machines.

In Figure 2, it is possible to observe that all the curves at the time before subsoiling in both treatments behaved in a similar way, with increasing PR values up to the $40 \mathrm{~cm}$ layer and decreasing in depth for all the sampling points. After the subsoiling, the AS- 40 and AS-50 treatments showed a reduction in the $\mathrm{PR}$ values at depth compared to the values found at the BS- 40 and BS- 50 moments.

It is noted that there was an increase in $\mathrm{PR}$ values in the BS-40 treatment below the subsoiler working depth $(40 \mathrm{~cm})$. There was no increase in PR in the BS-50 below the working depth of $50 \mathrm{~cm}$. This fact can be explained by the difference in soil moisture conditions in the AS- 40 area when the soil was drier (Figure 1) than the BS-40 moment.

After the subsoiling (AS-40 and AS-50), mean PR values that were above the $C L$ in the $0 \mathrm{~cm}$ to $30 \mathrm{~cm}$ layer decreased at all sampling points, except for the BFP, where the subsoiling rod did not work. This fact demonstrated the positive effect of subsoiling on reducing PR values, not only in depth (vertical), but also in the width of the furrow line (horizontal).

The $\mathrm{PR}$ curves at the $\mathrm{CP}, \mathrm{P}+20$ and $\mathrm{P}-20$ were those that showed the greatest reduction in soil PR values in comparison to the AS moment. This fact is due to the proximity of the sampling points at the center of the furrow, where the subsoil rod was more active, causing greater rupture of the compacted layers and mobilization of the soil, thus contributing to better soil preparation. Therefore, this fact demonstrates the importance of greater soil mobilization in sandy texture conditions.
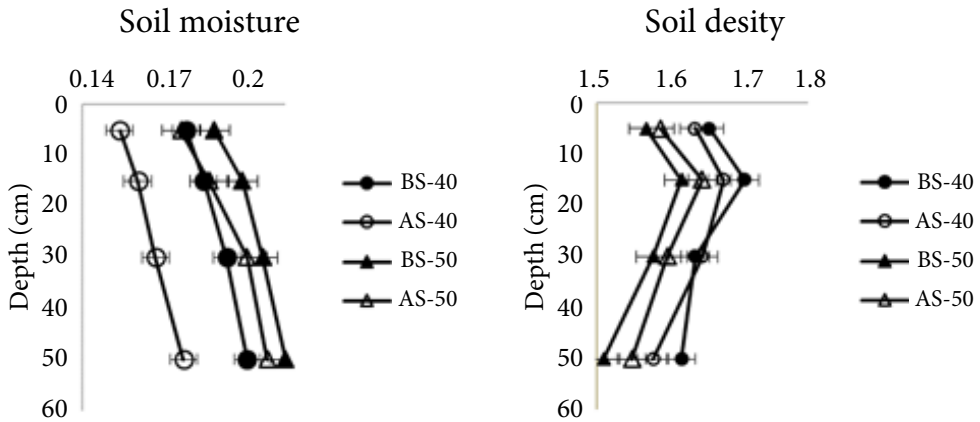

Figure 1. Soil moisture $\left(\mathrm{m}^{3} \mathrm{~m}^{-3}\right)$ and density $\left(\mathrm{Mgm}^{-3}\right)$ at depths of $0 \mathrm{~cm}$ to $60 \mathrm{~cm}$, in the moments before (BS) and after (AS) the subsoiling treatments. The bars indicate the values of standard error of the mean and the overlap of these denotes the absence of differences between the means of the different tillage moments. BS-40: before subsoiling at $40 \mathrm{~cm}$; AS-40: subsoiling only at $40 \mathrm{~cm}$; BS-50: before subsoiling at $50 \mathrm{~cm}$; AS-50: subsoiling only at $50 \mathrm{~cm}$. 


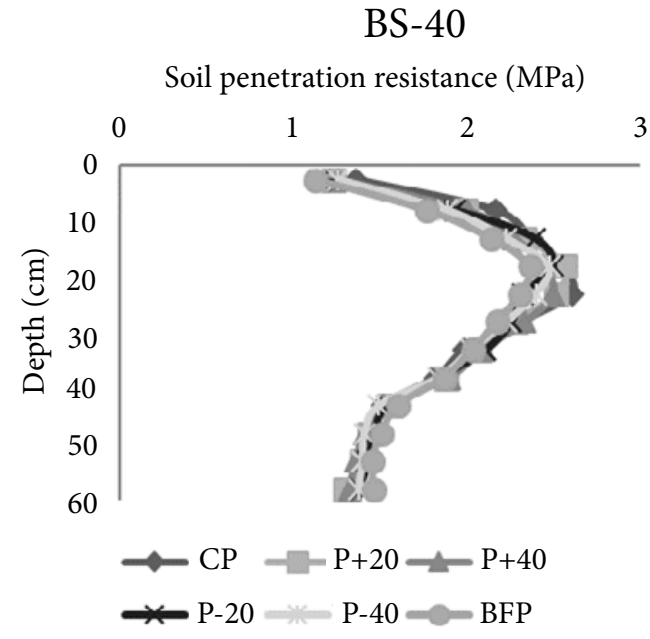

AS-40

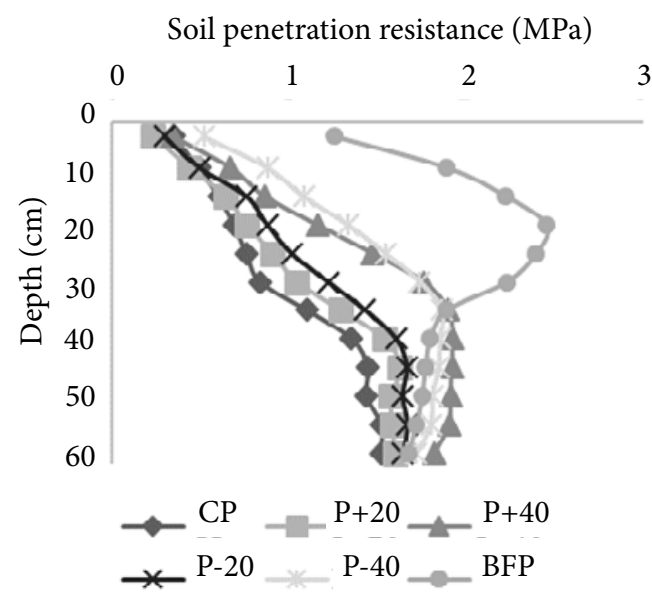

BS-50

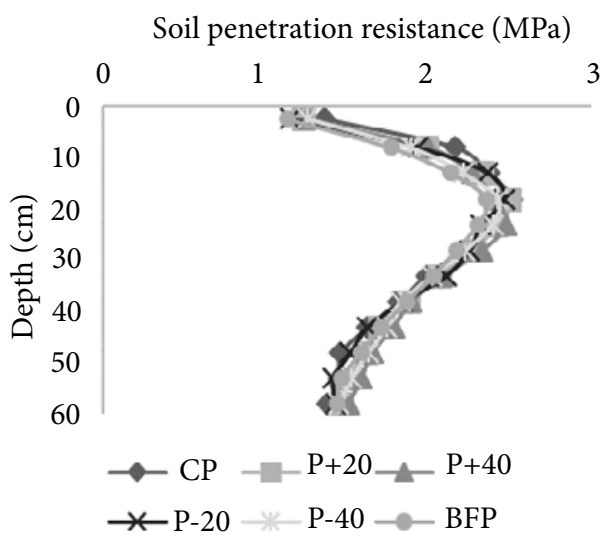

AS-50

Soil penetration resistance $(\mathrm{MPa})$

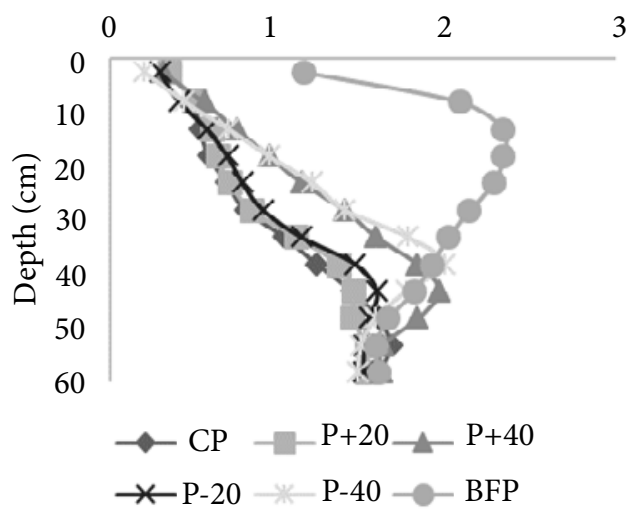

Figure 2. Curves resulting from mean PR values as a function of soil depth at the BS- 40 and BS-50 moments of the AS-40 and AS-50 treatments.

Sample points $=$ CP: Center point of the furrow; $\mathrm{P}+20$ : point $20 \mathrm{~cm}$ to the right; $\mathrm{P}+40$ : point $40 \mathrm{~cm}$ to the right; $\mathrm{P}-20$ : point $20 \mathrm{~cm}$ to the left; $\mathrm{P}-40$ : point $40 \mathrm{~cm}$ to the left; BFP: between furrow point; CL: critical limit.

\section{CONCLUSIONS}

The different subsoiling depths influenced the soil PR values, with their reduction in depth of work (vertical) and width of the furrow line (horizontal).

There was a decrease in PR values below the subsoiler working depth in the AS- 50 treatment caused by the subsoiling equipment's rod action.

The subsoiling depth at $50 \mathrm{~cm}$ was more suitable for preparing the soil aiming at planting forest stands in sandy red-yellow latosol due to the lower PR values in the soil and the greater soil tillaging in the planting line.

\section{ACKNOWLEDGEMENTS}

The authors are thankful for the Coordination for te Improvement of Higher Education Personnel (Capes) for the scholaeship and for the forest company for the support and concession of the study area.

\section{SUBMISSION STATUS}

Received: 1 May, 2017

Accepted: 30 June, 2018 


\section{CORRESPONDENCE TO}

\section{Eduardo da Silva Lopes}

Universidade Estadual do Centro-Oeste

(Unicentro), PR 153, km 7, s/n, CEP 84500-000,

Irati, PR, Brasil

e-mail: eslopes@unicentro.br

\section{REFERENCES}

Almeida CX, Centurion JF, Freddi OS, Jorge RF, Barbosa JC. Funções de pedotransferência para a curva de resistência do solo à penetração. Revista Brasileira de Ciência do Solo 2008; 32(6): 2235-2243. 10.1590/S0100-06832008000600003

Bentivenha SRP, Gonçalves JLM, Sasaki CM. Mobilização do solo e crescimento inicial do eucalipto em função do tipo de haste subsoladora, profundidade de trabalho e características do solo. Engenharia Agrícola 2003; 23(3): 588-605

Empresa Brasileira de Pesquisa Agropecuária Embrapa. Manual de métodos de análises de solo. 2nd ed. Rio de Janeiro: Ministério da Agricultura e do Abastecimento; 1997.

Grotta DCC, Lopes A, Furlani CEA, Branquinho KB, Reis GN, Silva RP. Subsolador: avaliação do desempenho em função da velocidade de trabalho e espaçamento entre hastes. Acta Scientiarum Agronomy 2004; 26(1): 21-26. 10.4025/actasciagron.v26i1.1951
Pedrotti A, Pauletto EA, Crestana S, Ferreira MM, Dias MS Jr, Gomes AS, Turatti AL. Resistência mecânica à penetração de um planossolo submetido a diferentes sistemas de cultivo. Revista Brasileira de Ciência do Solo 2001; 25(3): 521-529. 10.1590/S0100-06832001000300001

Pincelli ALPS, Seixas F, Nunes R. Compactação e fertilidade do solo após colheita do eucalipto utilizando Feller Buncher e Skidder. Cerne 2014; 20(2): 191-198. 10.1590/01047760.201420021414

Ralisch R, Miranda TM, Okumura RS, Barbosa GMC, Guimarães MF, Scopel E, Balbino LC. Resistência à penetração de um latossolo vermelho amarelo do cerrado sob diferentes sistemas de manejo. Revista Brasileira de Engenharia Agrícola e Ambiental 2008; 12(4): 381-384. $10.1590 /$ S1415-43662008000400008

Ribon AA, Tavares Filho J. Estimativa da resistência mecânica à penetração de uma latossolo vermelho sob cultura perene no norte do estado do Paraná. Revista Brasileira de Ciência do Solo 2008; 32(5): 1817-1825. 10.1590/S0100-06832008000500003

Rodrigues CK, Lopes ES, Polizeli KMVC, Müller MML. Soil compaction due to wood harvesting traffic at different extraction distances. Floresta Ambiente 2018; 25(2): e20160045. 10.1590/2179-8087.004516

Souza ZM, Campos MCC, Cavalcante IHL, Marques J Jr, Cesarin LG, Souza SR. Dependência espacial da resistência do solo à penetração e teor de água do solo sob cultivo contínuo de cana-de-açúcar. Ciência Rural 2006; 36(1): 128-134. 10.1590/S0103-84782006000100019 